\title{
Death Avoidance Behavior of Accidentally Injured Cub in Platyrrhini: An Opportunistic Observation Record
}

\author{
Romes Bittencourt Nogueira de S, ${ }^{*}$ Carlene Gomes R, Natália Carvalho de C, Laura Carvalho de C
}

Institute of Biological Sciences, Federal University of Goias, Brazil

\begin{abstract}
Introduction: Infraorder Platyrrhini is composed of species with complex social structures, but information about their interaction with death is scarce in the literature, as already registered for old world monkeys. This work concern of death avoidance behavior recorded in a group of Callithrix penicillata (E. Geoffroy, 1812) (Primates, Callitrichidae).

Material and Methods: This is a study made it through opportunistic observation of an interaction between a mother and her cub, accidentally injured and on the deathbed. The detailed description of the phenomenon occurred through all occurrence sampling, and was counted on the testimony of local residents. For better data exposure, an etogram was constructed, containing all the observed behaviors, in sequence, from the beginning to the end of the sampling.
\end{abstract}

Results: In all, 10 individuals participated in the observations, and 16 behavioral acts were observed during 6 days of observation of the interaction mother-child injured-other individuals. The behaviors indicated a high degree of stress on the part of all involved, as well as the mother's attempt to withdraw her cub from the area in which was. The mother also tried to bring it to your back. There were other individuals in the group, possibly to assist in caring for the cub. ${ }^{1}$

Conclusion: This work is unpublished for the specie in question and reaffirms its social character. The observations open spaces for further investigation into similar behaviors in human and non-human primates as well as the phylogenetic relationship between them.

Keywords: Callithrix penicillata, Commom marmosets, Death, Ethology

\section{Introduction}

The Platyrrhini infraorder is composed of species that have different social structures. They can form monogamous or polyandrous systems, harem, or groups in which males and females mate freely with each other. ${ }^{1,2}$ This complex social dynamic gives the monkeys strong parental care, which can lead to altered behavior towards the death of individuals in the group. It has already been observed that in some groups of animals there are typical behaviors in relation to avoiding death. Park et al. ${ }^{3}$ reported a group of dolphins helping a fainting individual to swim. Several works report similar behaviors in Old World monkeys. ${ }^{4-11}$ However, there are few works that report similar behavior in specimens of the Platyrrhini infra-order. In an exemplary study, Bezerra et al. ${ }^{12}$ presented the care of a male $C$. jacchus with his dying wife.

This study was due to an opportunistic observation of the team from the Psychobiology Sector of the Federal University of Goiás in relation to a group of black-tufted-ear marmosets, the popular name to the Callithrix penicillata E. Geoffroy, 1812 (Primates,

\begin{tabular}{|l|l|}
\hline Quick Response Code: & Porresponding author: Death Avoidance Behavior of Accidentally Injured Cub in Platyrrhi- \\
ni: An Opportunistic Observation Record \\
Received: 28 October, 2021 \\
Citation: Nogueira de SRB, Gomes CR, Carvalho de CN, Carvalho de CL. Death Avoidance \\
Behavior of Accidentally Injured Cub in Platyrrhini: An Opportunistic Observation Record. J \\
Psych Sci Res. 2021;1(4):1-4. DOI: 10.53902/JPSSR.2021.01.000520
\end{tabular}


Callitrichidae). These are New World primates and their groups are predominantly matriarchal. In these, the new borns are taken care of by other members of the group, which are usually their older siblings.

This study is justified due to the very limited literature on the subject, especially for the specie $C$. penicillata. We hope that this work will contribute to the understanding of death avoidance behaviors in humans and non-humans.

\section{Methods}

The observations took place during the month of April - 2019, during a study on the behavioral repertoire of $C$. penicillata in a typical cerrado area, in the rural area of the Trindade county, Goiás, Brazil (-16.6414705, -49.4696579). The detailed description of the observed behaviors included testimonies from members of the research team and local residents who witnessed the acts. All behavioral sampling was done by sampling all occurrences ${ }^{13}$ of the mother-injured offspring-other individuals interaction. Due to the lack of resources and the lack of expectation of the observed phenomenon, it was not possible to record photos or videos. For better data exposure, an ethogram was constructed, containing all observed behaviors in sequence, from the beginning to the end of the sampling. The individuals involved were also nicknamed, in order to facilitate the identification and construction of this work.

\section{Results}

The observations took place on April 4, 5, 6, 7 and 8, 2019, in the afternoon, starting at approximately 4:00pm, with cloudy weather.

\section{First day - April 4, 2019}

5 individuals of $C$. penicillata, 3 of them adults (two females and one male), and 2 male offspring, foraging in a star fruit tree (Averrhoa carambola), apparently looking for insects, since the individuals did not eat the fruits. One of the infants, Max, got off the back of his mother, Lucy, and walked over the branches until he fell from a height of approximately 10 feet, crashing heavily into the ground.

At this point, Lucy quickly descended from the tree, going to meet her offspring. Max vocalized sharply without breaks. After approximately 1 minute, three of the other marmosets also came down from the tree and began to surround Max, who was suffering on the ground.

Lucy was moving her arms, pulling Max and vocalizing sharply. The other monkeys were also vocalizing, and they walked quickly around Max, apparently performing guarding behavior or stereotyping. Only Lucy manipulated the offspring, in an attempt to drag it to another location, apparently on its back.
Lucy remained with the behavior of bringing Max to her for approximately 1 hour. After this period, she left the place, returning about two hours later, with the presence of another 6 individuals, who we could not identify the sex.

During the period when the mother was away, the offspring continued to vocalize, but the other individuals still surrounded him. After her arrival, Lucy continued to manipulate him uninterruptedly, stopping only at nightfall (around 07:30pm, Brasília time).

Around 08:20pm, a resident of the region removed Max from the ground and took him to another area, with a greater presence of trees. Neither the researchers nor the residents observed any behavior of the other marmosets during the night. In this one, there was heavy rain, which led several local residents to deduce that Max had passed away.

\section{Second day - April 5, 2019}

In the next day, the researchers were woken up at 5:40am, with high and uninterrupted vocalizations from the marmosets, who returned to surround Max, this time under a mulberry tree (Morus sp.), the same place where the resident had left him in the last day.

The researchers followed the movement of the animals, which were unsuccessful in removing Max from the ground. Hugging and sniffing behaviors were observed from Lucy to her son. Her mother was vocalizing very strongly, apparently stressed by the situation she was going through. The guard behavior, sharp and uninterrupted vocalization, hugs and smells were followed with variations in their execution orders until approximately 9:30am, when all the marmosets left Max for the last time. Max no longer vocalized and emitted behaviors, other than standing still and breathing deeply.

At approximately 10:00am, a dog (Canis domesticus) passed the spot where Max was stretched out, snapped him up and took him to a place where the researchers no longer spotted him. The residents were also unable to inform of Max's whereabouts. It is hypothesized that he has, unfortunately, died.

Third, fourth, fifth and sixth days - 06, 07, 08, 09 and 10 April, 2019

For four days after the event, Lucy and other members of her group (in varying numbers) continued to frequent the place where Max was last seen. Upon reaching under the mulberry tree, the mother emitted vocalizations, increased locomotor activity, scratched herself intensely, sniffed and dug the ground. From the fifth day onwards, neither Lucy nor other marmosets were seen at the site.

Below is an ethogram of the main patterns of behavior, in sequence, observed by the individuals in this interaction Table 1. 
Table 1: The ethogram briefly presents the behaviors observed during Max's death avoidance attempt.

\begin{tabular}{|c|c|c|c|c|c|c|c|}
\hline & 04-Apr & 05-Apr & 06-Apr & 07-Apr & 08-Apr & 09-Apr & 10-Apr \\
\hline Max & $\begin{array}{l}\text { Fall from the star } \\
\text { fruit tree; Deep } \\
\text { breathing, difficulty } \\
\text { moving upper and } \\
\text { lower limbs. High } \\
\text { and uninterrupted } \\
\text { vocalizations. }\end{array}$ & $\begin{array}{l}\text { Deep breathin, } \\
\text { difficulty moving } \\
\text { upper and lower } \\
\text { limbs. High and } \\
\text { uninterrupted } \\
\text { vocalizations }\end{array}$ & No records. & No records. & No records. & No records. & No records. \\
\hline Lucy & $\begin{array}{l}\text { Before the fall, } \\
\text { forage. After the } \\
\text { fall, sharp and } \\
\text { uninterrupted vo- } \\
\text { calizations (alarm/ } \\
\text { recruitment), } \\
\text { tugging, trying to } \\
\text { bring Max closer. }\end{array}$ & $\begin{array}{l}\text { Sharp and uninter- } \\
\text { rupted vocaliza- } \\
\text { tions (alarm/ } \\
\text { recruitment), } \\
\text { tugging, trying to } \\
\text { bring Max closer. } \\
\text { Hugs, face close, } \\
\text { appearing to sniff } \\
\text { Max. }\end{array}$ & $\begin{array}{l}\text { Non-periodic } \\
\text { visits to the } \\
\text { study area. } \\
\text { High-pitched } \\
\text { vocalizations. } \\
\text { Smell soil and } \\
\text { dig where Max } \\
\text { has been. }\end{array}$ & $\begin{array}{l}\text { Non-periodic } \\
\text { visits to the } \\
\text { study area. } \\
\text { High-pitched } \\
\text { vocalizations. } \\
\text { Smell soil and } \\
\text { dig where Max } \\
\text { has been. }\end{array}$ & $\begin{array}{l}\text { Non-periodic } \\
\text { visits to the } \\
\text { study area. } \\
\text { High-pitched } \\
\text { vocalizations. } \\
\text { Smell soil and } \\
\text { dig where Max } \\
\text { has been. }\end{array}$ & $\begin{array}{l}\text { Non-periodic } \\
\text { visits to the } \\
\text { study area. } \\
\text { High-pitched } \\
\text { vocalizations. } \\
\text { Smell soil and } \\
\text { dig where Max } \\
\text { has been. }\end{array}$ & $\begin{array}{l}\text { Non-periodic } \\
\text { visits to the } \\
\text { study area. } \\
\text { High-pitched } \\
\text { vocalizations. } \\
\text { Smell soil and } \\
\text { dig where Max } \\
\text { has been. }\end{array}$ \\
\hline $\begin{array}{l}\text { Other in- } \\
\text { dividuals }\end{array}$ & $\begin{array}{l}\text { High and uninter- } \\
\text { rupted vocaliza- } \\
\text { tions. Surrounding } \\
\text { Max, and agitation } \\
\text { (possibly guarding } \\
\text { behavior or stereo- } \\
\text { typy) }\end{array}$ & $\begin{array}{l}\text { Surrounding Max, } \\
\text { and agitation } \\
\text { (possibly guarding } \\
\text { behavior or stereo- } \\
\text { typy). }\end{array}$ & $\begin{array}{l}\text { Brief vocaliza- } \\
\text { tions. Smell soil } \\
\text { and dig where } \\
\text { Max has been. }\end{array}$ & $\begin{array}{l}\text { Brief vocaliza- } \\
\text { tions. Smell soil } \\
\text { and dig where } \\
\text { Max has been. }\end{array}$ & $\begin{array}{l}\text { Brief vocaliza- } \\
\text { tions. Smell } \\
\text { soil and dig } \\
\text { where Max has } \\
\text { been. }\end{array}$ & $\begin{array}{l}\text { Brief vocaliza- } \\
\text { tions. Smell } \\
\text { soil and dig } \\
\text { where Max has } \\
\text { been. }\end{array}$ & $\begin{array}{l}\text { Brief vocaliza- } \\
\text { tions. Smell } \\
\text { soil and dig } \\
\text { where Max has } \\
\text { been. }\end{array}$ \\
\hline
\end{tabular}

\section{Discussion}

Upon noticing her offspring's fall, Lucy quickly descended from the carambola tree, which signals maternal protection behavior. Proximal causes of this behavior are already mentioned in the literature as due to the oxytocinergic modulation that marks the mother, and to a lesser degree, the other siblings. Oxytocin is a very important neurotransmitter for the group organization of human and non-human primates. ${ }^{14}$

The vocalization emitted by Max was possibly crying. Crying in the face of adversity, usually linked to pain, is generally a typical mammalian behavior. ${ }^{15,16}$ The vocalization of Lucy and the other siblings was most likely an alarm/recruitment, signaling the need for help from other individuals in the group. This hypothesis is realized when we observe that immediately after Lucy's initial vocalizations, most of the other monkeys immediately descended from the star fruit tree and positioned themselves around Max.

Unlike what was observed by Bezerra et al. ${ }^{12}$ the other individuals in the group were able to approach the injured animal. Their sudden movements and vocalizations could indicate guarding or recruiting behavior for other individuals, however, this hypothesis could not be corroborated, since other individuals were not seen in the place. Recruitment behaviors are extremely common in social animals. They can occur in situations of visible food, presence of predators, among others. ${ }^{17,18}$

The other individuals in the group, Lucy's children, also exhibited behaviors linked to psychomotor agitation during the first hours of observation. These can either be guard behaviors, aimed at protecting the injured individual, or stereotyped behaviors, in this case, indicating stress. If the second hypothesis is concrete, and in view of all that has been observed, there is a real possibility of compassion as a uniting link in the group in question, as also confirmed by the pioneering study by Bezerra et al. ${ }^{12}$

However, the idea of compassion is not fully supported by this study, since, when night fell, all individuals departed for possibly their resting place, leaving Max injured alone on the ground. This allowed residents to remove the baby from the ground and take it to another, more wooded location. It is important to emphasize that primates, in general, have a well-established resting place and chronobiological activity. ${ }^{19,20}$ Thus, if Lucy stayed with her baby all night, even if accompanied by her other children, she would be submitting herself to great risks, such as predation by nocturnal animals.

The next day, Lucy and seven other members of the group, return to meet Max, already removed to another location. Vocalizations and psychomotor agitation follows, evidencing the mother's probable attempt to remove her baby from the ground and take him to a shelter. One issue stands out at this point: Lucy and the monkeys who were "taking care" of Max gave up their usual habits of life, as, according to the literature, early morning is usually the time used by many Plathyrrini for foraging and food. ${ }^{19,20}$ The behaviors observed show that Lucy's emotional state affected her routine in such a way that she did not care whether or not she had met her basic needs, such as food and water. Old world humans 
and monkeys, when under high stress situations, can also show behaviors of even physiological deprivation, feeding and thirst. ${ }^{21}$

The dog's snapping took the observations of the group's social interactions, and possibly also Max's life. However, we observed behaviors indicative of mourning, or of not locating the individual, since, for another four days, the monkeys always returned. in the morning, to the place where Max was. The literature also describes mourning behaviors in non-human primates, but above all, in old world monkeys. ${ }^{7-11}$ At this location, individuals elicited vocalizations, sniffing the ground, and digging. The behavior of sniffing and vocalizations had also been observed by Bezerra et al. ${ }^{12}$

Among the limitations of this study is the impossibility of taking photographs and filming, however, this did not prevent the recording of all behavioral acts performed by the individuals in question. In short, this work presents the interaction between mother and her children in an attempt to avoid the death of an accidentally injured offspring. This reaffirms the social character of these individuals and also opens spaces for further investigations about similar behaviors in human and non-human primates, as well as the phylogenetic relationship between them.

\section{Acknowledgment}

We would like to thank the Psychobiology Sector of the Federal University of Goiás for the physical and theoretical basis for the development of this study, as well as expressing our thanks to Mr. William Bettencourt, Ms. Martha Agapito and Ms. Julia Bettencourt for their contributions in the details of the narrated case.

\section{Funding}

None.

\section{Conflicts of Interest}

Author declares that there is no conflict of interest.

\section{References}

1. Plavcan JM. Sexual dimorphism in primate evolution. American Journal of Physical Anthropology: The Official Publication of the American Association of Physical Anthropologists. 2001;116(S33):25-53.

2. Rosenberger AL. Evolutionary morphology, platyrrhine evolution, and systematics. The Anatomical Record: Advances in Integrative Anatomy and Evolutionary Biology. 2011;294(12):1955-1974.

3. Park KJ, Sohn H, An YR, et al. An unusual case of care-giving behavior in wild long-beaked common dolphins (Delphinus capensis) in the East Sea. Marine Mammal Science. 2013;29(4):E508-E514.

4. Kaplan J. Responses of mother squirrel monkeys to dead infants. Primates. 1973;14(1):89-91.
5. Boesch C. Teaching among wild chimpanzees. Animal behaviour. 1991;41(3):530-532.

6. Nakamichi M, Koyama N, Jolly A. Maternal responses to dead and dying infants in wild troops of ring-tailed lemurs at the Berenty Reserve, Madagascar. International Journal of Primatology. 1996;17(4):505523.

7. Fawcett K, Muhumuza G. Death of a wild chimpanzee community member: possible outcome of intense sexual competition. American Journal of Primatology: Official Journal of the American Society of Primatologists. 2000;51(4):243-247.

8. Biro D, Humle T, Koops K, et al. Chimpanzee mothers at Bossou, Guinea carry the mummified remains of their dead infants. Current Biology. 2010;20(8):R351-R352.

9. Fashing PJ, Nguyen N, Barry TS, et al. Death among geladas (Theropithecus gelada): a broader perspective on mummified infants and primate thanatology. Am J Primatol. 2011;73(5):405-409.

10. Cronin KA, van Leeuwen EJ, Mulenga IC, et al. Behavioral response of a chimpanzee mother toward her dead infant. Am J Primatol. 2011;73(5):415-421.

11. Stewart FA, Piel AK, O'Malley RC. Responses of chimpanzees to a recently dead community member at Gombe National Park, Tanzania. Am J Primatol. 2012;74(1):1-7.

12. Bezerra BM, Keasey MP, Schiel N, et al. Responses towards a dying adult group member in a wild New World monkey. Primates. 2014;55(2):185-188.

13. Altmann J. Observational study of behavior: sampling methods. Behaviour. 1974;49(3-4):227-266.

14. Churchland PS, Winkielman P. Modulating social behavior with oxytocin: how does it work? What does it mean? Horm Behav. 2012;61(3):392-399.

15. Todt D. Serial calling as a mediator of interaction processes: crying in primates. In Primate vocal communication. Springer, Berlin, Heidelberg. 1988: pp. 88-107.

16. Zeifman DM. An ethological analysis of human infant crying: answering Tinbergen's four questions. Developmental Psychobiology: The Journal of the International Society for Developmental Psychobiology. 2001;39(4):265-285.

17. Jasper JM, Poulsen JD. Recruiting strangers and friends: Moral shocks and social networks in animal rights and anti-nuclear protests. Social problems. 1995;42(4):493-512.

18. Couzin ID. Collective cognition in animal groups. Trends in cognitive sciences. 2009;13(1):36-43.

19. Donati G, Borgognini Tarli SM. From darkness to daylight: cathemeral activity in primates. Journal of Anthropological Sciences. 2006;84(1):732.

20. Erkert HG. Diurnality and nocturnality in nonhuman primates: comparative chronobiological studies in laboratory and nature. Biological Rhythm Research. 2008;39(3):229-267.

21. Parker KJ, Buckmaster CL, Sundlass K, et al. Maternal mediation, stress inoculation, and the development of neuroendocrine stress resistance in primates. Proc Natl Acad Sci USA. 2006;103(8):3000-3005. 